\title{
China's BRI: Regional Prospects and Implications
}

\author{
Dr. Iram Khalid, Chairperson ${ }^{1 *}$, Dr. Muhammad Iqabl Chawla ${ }^{2}$ \\ ${ }^{1}$ Professor, Department of Political Science, University of the Punjab, Lahore. \\ ${ }^{2}$ Professor, Former Chairman, Department of History, University of the Punjab, Lahore.
}

\begin{abstract}
Belt and Road Initiative (BRI) by China has emerged as one of the most important factors in the upcoming global politics. This plan can impact both regional and global politics. There are multidimensional and multifaceted repercussions of BRI for the international global politics. This paper describes the details of BRI, the micro-plans which are being planned under this program. Then, it enlists the economic and international politics benefits which China would gain from this plan. After that, this paper enumerates the possible benefits of BRI for the regional countries like Pakistan. In addition to that, this paper also highlights the possible global and regional challenges which China might face while completing and getting benefits out of this plan. After conducting a critical analysis of BRI's trajectory, its possible global and regional repercussions for the emerging international politics, its benefits for China and the possible challenges this paper concludes that no matter how beneficial this plan can be for Chinese global economic position there are multiple challenges which China will have to tackle with. Otherwise, BRI can lose its potential economic and global benefits both in the region and in the larger world politics.
\end{abstract}

Keywords

BRI, CPEC, China, regional Politics, Global politics.

Article Received: 20 September 2020, Revised: 30 November 2020, Accepted: 18 December 2020

\section{Introduction}

Ever since the end of cold war, US has enjoyed global economic and political hegemony. However, this status of unipolar world did not come without challenges. In the postcold war era, proponents of a multipolar world had great expectation with the Britain and the European Union not only for the contribution in the global economy but also pose challenge to the US ever enhancing role. These hopes sadly, could not be fulfilled. The twentieth century predominately remained under the economic hegemony of USA. Many counter efforts having also been carried out to build up meaningful challenge to the US advancements. Notable among them are the economic reforms of China in the decade of 70s. Gradually, China's economic rise became evident. By gauging the extent and prowess of China's economic efforts, the scholars have started to regard $21^{\text {st }}$ century as the Asian century with eminent role of China. Currently, China dominates the world markets with a share of $15 \%$ in the global economy; only $2.6 \%$ less than the United States (Chohan, 2018). China's annual GDP growth has already surpassed United States'. While both of the countries are intertwined in a web of economic interdependence, both of them are trying to break free of each other's influence and establish itself as the sole economic power of the world. In this ongoing economic tussle between China and US, Belt and Road Initiative (BRI) has become almost a deal breaker in establishing economic supremacy of China on the globe. BRI can prove a strategic game changer in the Asia Pacific but also as a factor of changing behaviors of actors around the world. The BRI initiative targets the infrastructure gap between the countries of Asia Pacific and Eastern Europe and aims to cement those trade links to complete a chain of trade routes which has the potential of transforming Chinese trade routes. It involves the creation of roads, bridges, railways, ports to rebrand what China perceives as the "New Silk Road" propelling China into a new age of globalization and economic dominance (Chohan, 2018, Huang, 2016). BRI has far reaching implications for states around the world. BRI does not only leverages China in terms of its economy but also expands its political influential and minimized security challenges and along the strategically important periphery. Even though many Chinese scholars like Zhang Yunling portray BRI as integral for China's internal survival, others call it a Chinese 'Grand Strategy' to increase the China influence in the world.

\section{Cardinal Rationale of BRI:}

BRI was announced by President Xi Jinping in 2013. 'Belt and Road initiative' (BRI) is also Termed as 'One Belt one Road' (OBOR). In the words of Chinese Government, it is an initiative to improve Regional cooperation through Connectivity, en route to Enlightened Future. In the beginning, the centre of concern has been construction and development of the infrastructure, education, highways and railways, power supply and resources. Belt and road Initiative has been taken to develop bilateral and multilateral cooperation system, to enhance the mechanism of economic integration, supporting the trade flow. Moreover 'Belt and Road initiative', is an invite to all countries, such that more than sixty countries in the regions like Middle East, Asia, Eastern Europe and Africa are in consideration. Belt and Road Initiative is actually a multi-decade project that has been established to re-fix the commercial image of China by enabling it to engage with the world (Ling \&Perrigoue, 2018). This is China's involvement into global market at a huge level. Belt and Road Initiative signify two different perspectives, in this initiative- the Belt is based on land reforms and Corridors that aims to connect two of the world's largest economies Europe and China through 
Central Asia that will act as a tran-shipment hub. On the other hand, is Maritime Silk road, an Opportunity for worlds $42 \%$ population, a road that will pass through Southeast Asia, South Asia, Middle East and East Africa, providing medium for reforms to world's multinational corporations. Furthermore, China is not the only one financing and commercializing the Belt and road Project, the financiers include Chinese Development Bank, Silk Road Fund that was established in 2014, whereas, External financiers in BRI countries Include Asian Infrastructure Development Bank (AIIB) that was established in 2015 with an initial capital of 100 billion US dollars, and New Development Bank established under Association of Emerging Economies BRICS countries. Until 2030, China also hopes for investment from foreign governments and multilateral banks. The belt and road initiative, in the coming years is a 350 billion US dollars project. In the global arena, Belt and Road initiative is serving as a centre of concern for the policymakers, businessmen and debaters. This concern involves the investigation over China's Economic, political, social and strategic security. Such a massive investment requires actors to play a meaningful role behind the scene (Ling \&Perrigoue, 2018).

BRI is known as One Belt, One Road (OBOR) as well. It is considered "one of President Xi's most ambitious foreign and economic policies" (Cai 2017). It is a huge plan which aims at strengthening China's economic leadership through infrastructure building throughout the regions related to China. Most of the times it is viewed "through a geopolitical lens" as an "attempt to gain political leverage over its neighbours" (Cai, 2017). This initiative will reap benefits for domestic, regional and global economies. Chinese president Xi Jinping mentioned BRI for the first time in his speech on 7 September 2013. In the memory of the ancient Silk Road of ancient times-a trade-route which connected China to Europe through South and Central Asia, Xi anticipated a five tiered plan:

1. Policy discussion on combined progress plans and regional assimilation among all countries along the Silk Road

2. Better road links and transport communications that would smooth the progress of creating an economic belt

3 . Reduction in the hurdles to trade and investment

4. Increased circulation of money together with currency convertibility and recognition of inter and intra-regional currencies

5. Increase in the exchanges among tourists, students, professionals researchers in various fields) to contribute to information and encourage understanding

There are certain strategic priorities associated with BRI, for instance, an increase in exports to BRI countries, to encourage industrial reorganization, reinforcing China's geopolitical position, supporting the RMB's global status, decrease manufacturing inundate and sustain China's "Go Global” policy (MacKenzie, 2018, p.6).

Basically, this initiative is an amalgamation of two plans, first, to build "a 21st Century Maritime Silk Road" and "a Silk Road Economic Belt". Its major aims are connectivity of facilities, policy coordination, unhampered trade, financial assimilation and regional bonding. Any country and organization can become a part of BRI but official documents stress the significance of above 60 countries in the Middle East, Asia, Eastern Europe and Eastern Africa.

The major investments have been made in the fields of energy and mining and infrastructure. The maritime "Road", one of its plans, will be a main prospect for consumers and industrial corporations "as it accounts for $63 \%$ of the global population and $44 \%$ of its GDP, excluding China" and major BRI projects will be "worth USD 350 billion" (MacKenzie, 2018).

There are multiple analysis being done on the implications of BRI on South Asia (Singh, 2019, The Diplomat; Singh, 2019, Lowa Institute; Baruah 2018), Southeast Asia (Jie, 2018), Central Asia (Laruelle, 2018) and Europe (RAND 2018). This paper will especially focus on BRI's implication in the South Asian region.

\section{Regional Prospects of BRI}

The Belt and Road Initiative, like any other economic project, proposes a transactional model for its stakeholders. Its prospects and challenges go side by side. For Asia, the region which is largely the theatre of Chinese ambitions, BRI provides economic opportunities as well as has geopolitical outcomes. While countries like Pakistan, Iran and Russia have expressed great enthusiasm over the ambitious project, China's immediate economic rival and neighbor India has abstained itself from the project and Indian scholars refer to it as a practical of China's imperialistic designs. For East Asian states BRI routes could diversify their economies and aid the Asian tigers to fulfill their dream by boosting their economies through the massive increase in market share that BRI promises (Small, 2017). However, the overarching control in Chinese hands worries the adversaries of South China Sea conflict who are already weary of Chinese dominance. For United States, BRI comes as a direct challenge to its objectives in Asia and threatens its status as the balancer and security provider in Asia Pacific. Moreover, the United States' already dwindling control over global economy falls, once China firms its economic grounds and lessens its dependence on US financial capital. Europe acknowledges the potential in BRI but voices its concerns over corruption, land grabbing and its regard for environmental concerns in these projects.

Scholars around the world have likened BRI to United States' Marshal Plan or the Chinese version of the Monroe Doctrine but despite the views of many on the implications BRI will have on its stakeholders, there is a general agreement on one thing: BRI is going to transform Chinese economy for the best. This is because BRI solves most of the problems that the Chinese economy is facing right now which are stopping it from further expansion. Firstly, China's rate of industrialization has increased so much that it has surpassed Chinese resources and the rate of accumulation of resources as well as the rate of trade. 
Chinese industries have the capacity to produce a lot more quantity of goods and services that it is currently utilizing. Embarking on the Belt and Road Initiative would include making bilateral agreements with resources rich countries around the route and then hunt for new markets to dispatch these goods. Eric Olander contrasts this model with British imperialism in these words: "OBOR is also reminiscent of Britain's old imperial trading network that was designed to extract natural resources from its colonial outposts and then sell back finished goods to these markets" (Mitrovic, 2018). The diversification of markets is the key to China's way to establishing economic hegemony. The opening of the African region to Chinese goods reduces the Chinese dependency on the Western hemisphere where it has been encountering a number of problems. The United States at often times is proven to be susceptible to increasing tariffs and duties on Chinese goods due to a building domestic pressure (Small, 2017). Furthermore, China's traditional exports of technology, telecommunication, solar panels and construction are currently directed towards Europe where markets for these are either already highly saturated or under the clasp of protectionist policies. As compared to that the countries around the Silk Road route like East Asian and Sub Saharan economies are developing countries with huge potential for Chinese products (Mitrovic, 2018).

Most importantly, with BRI becoming a reality, China's dependence on the US will dramatically decrease. The United States stands as a major roadblock in China's ambitions for an absolute economic hegemony due to the labyrinth of economic interdependence. The development of the six BRI routes will open up options for China to pass its goods. It can easily bypass the routes currently controlled by the US army and not give levy to them ensuring better security for its goods. BRI projects also provide a better investment opportunity for Chinese foreign reserves which are currently used to buy US government bonds reaping them relatively low interests. China can now invest in the infrastructure and communication projects which could capitalize on the trade in peace with neighboring countries enhancing the use of its currency and increasing its value. Moreover, China can ease its dependence on the conflicted Straits of Malacca from where presently $80 \%$ of Chinese energy imports are passed. Straits of Malacca are the bottleneck of conflict in South China Sea and takes up massive naval resources for China to maintain its military presence there and secure the conflicted route for its imports.

Finally, in order to finance these elaborate initiatives China does not turn to the global institutions like World Bank and International Monetary Fund (IMF) but instead chooses to rely on its own birth Childs Asian Infrastructure Investment Bank (AIIB) or the New Development Bank (NDB), The Shanghai Cooperation and the New Silk Road Fund. These are the institutions which are arguably politicized and well under Chinese control. Furthermore, unlike the World Bank and IMF, these financial bodies do not give loans contingent on good governance and human rights security which again suits the way China works (Basit, Torjesen\& Macfarlane, 2019).
While BRI is not the sole factor responsible for an emerging Chinese economic hegemony, it plays a key role in removing the obstacles in the way of Chinese dominance in the world. Rigorous analysis of the validity and circumference of BRI as an economic initiative highlights the far reaching prospects and challenges it proposes for the regional and global stakeholders. The case study of BRI suggests that China's economic dominance is imminent and the world around China has started to see a Chinese centuryat least in terms of economic hegemony.

Global Prospects of BRI:

Apart from the fear of China breaking free of US interdependence, USA has also got serious reservations regarding the increase of Chinese sphere of influence. BRI, inarguably creates a "China Circle" where loyalty to "one china' will be the overarching theme among participant countries. This means more diplomatic support in world affairs which would potentially take away a lot of US leverage. Thus, in case of recent incidents like US-China Trade War where both the countries were imposing tariff on the goods of others, more countries are likely to side with China because of their economic dependency on her (Mitrovic, 2018).

After the pivot to Asia policy, United States has started to take a keen interest in the Asia Pacific Region. USA is a step ahead and sent its naval fleet to the South China Sea to keep a check on alleged Chinese aggressions. Despite being a non-party to the conflict, US offers diplomatic and military support to claimants against China. BRI's success would mean that the regional ties with counties of the Asia Pacific are going to benefit from the economic corridors and the sea ports under the String of Pearls policy. Thus, USA could become irrelevant if this conflict dies down and USA cannot afford to do so. Furthermore, with projects like the Trans-Atlantic Partnership, US is trying its best to secure the Asia Pacific region and tap into the economic opportunities there instead of relying solely on the conflict ridden Middle East.

\section{Regional Implications:}

The enormity of BRI suggests some broader implications. As the project is under completion and its contours are still not evident. With a careful observation of developments so far some of the careful implications can be enumerated. Keeping in view the regional aspects, some implications on

Asia are explained below.

South Asia :The Belt and Road Initiative largely targets the Asian region and uses it as a connecting part to access Europe and Africa. South Asia, in this regard, is very significant not only because of its prime geostrategic location but also because of the presence of the most volatile yet important states in the region. India and Pakistan, the two nuclear neighbors of china along with the instable Afghanistan, pose both threats and opportunities for the region. 
There are multiple challenges which China is facing in South Asia related to BRI. First of all, there is a trust deficit between China and some regional important countries like India which considers it as a "unilateral initiative" (Madan 2016). They have serious reservations over China Pakistan Economic Corridor (CPEC) as Sameer Patil, a researcher at foreign policy think tank Gateway House previous and an assistant director at the Indian National Security Council asserts that CPEC is a key hindrance to Indian participation in the initiative (Cai, 2017). Secondly, more than half of IBR countries are politically unstable such as Pakistan which presents a major security hazard to Chinese personnel working there (Haider \&Dilawar, 2016).

China is quite conscious of the risks connected with execution of the BRI in South Asia. The challenges China is facing in the South Asia are multi-dimensional ranging from "political instability and unsustainable policies by different governments; threats and attacks by violent extremist forces; geopolitical rivalries; operational risks including unsustainable debt accumulation; and constraints put by issues like environment, culture, religion, and governance" (Singh 2019, The Diplomat). Chinese BRI can actually be a cause behind "Intensifying strategic imbalance" (Singh, 2019, LOWY Institute). Right now it is a complex situation which is testing Chinese wisdom. China is now reconsidering its BRI plan in South Asia and trying to focus more on resolving the collaboration issues with India and appropriately administering the rapport with smaller countries. Side by side China also wants to speed up economic and security collaboration with Afghanistan, Pakistan, and the adjacent neighbouring countries related to CPEC (Singh, 2019, LOWY Institute).

State level analysis in this regard is very important to gauge the implications of BRI in South Asia. Pakistan is a traditional friend of China and China plans to develop an economic corridor across the country to reach the warm waters of Arabian Sea through Gawadar Port. This provides China the shortest route to reach the Arabian Peninsula and the Gulf. This corridor not only significantly shortens China's distance to markets but also builds crucial infrastructure in a country like Pakistan which lacks resources to build on its networks and solidify trade opportunities (Javaid, 2016). Under CPEC, a vast network of railways, special industrial units and link roads and highways will be created which would have an estimated value of more than $\$ 62$ billion as of 2017 . The China Pakistan Economic Corridor (CPEC) is thus termed as the 'game changer' for the region as once the infrastructure is created, counties like Iran and Afghanistan can also potentially benefit from the routes (Wolf, 2016).

However, the biggest setback CPEC might face in the region is that of terrorism and political instability in Pakistan. Even though, after Zarb-e-Azb Operation the country's jihadi elements have been reduced to a great extent, their scattered presence in the country is still a fact. In the past, these groups have often engaged in the kidnapping of Chinese engineers and citizens to use as a bait to get their demands met. Hence, the security of Chinese officials is a huge concern. Furthermore, the political instability of Pakistan means that with the change in governments so frequently, the political manifestos of each party might differ. This was the case after the 2018 elections when the government of Nawaz Sharif, which was viewed as very pro-Chinese party, was replaced by a somewhat apprehensive government of PTI. These political shifts in Pakistan stagger the progress of BRI (Wolf, 2016; Ahmad, Arshad, Mahmood \& Akhtar, 2017).

Though Afghanistan has signed a bilateral agreement with China to cooperate for the future prospects of BRI, Afghanistan's instability and the trickle-down effect of Afghan terrorist resistance in areas of FATA and GB could potentially harm the western routes of CPEC. India, which has an ambivalent relation with China boycotted the BRI Summit and voices serious concerns over the route of CPEC. According to India, CPEC passes through Gilgit Baltistan which is a conflicted territory. To appease India and include the regional power into the folds of BRI is a major challenge for China. In the absence of which, India with US backing might attempt to sabotage BRI's potential just like it tried to do so by financing the development of Chabahar Port in Iran to serve as a counter to Gawadar Port. These acts would create regional splits and start a new power struggle in the region which can turn into a violent conflict. Thus, China in order to secure its economic activities through BRI needs to pitch-in a more inclusive model to India (Blanchard,2018; Wolf, 2016).

\section{Central Asia:}

Central Asia, home to historical routes used by famous dynasties and conquerors of the world like Taimur, Alexander the Great, the Mughals, is also a land rich of natural resources. The five countries of Central Asia are the hub of natural resources and serve as the connecting point between Europe and Asia.

Being a region in close proximity with Central Asia, China has already invested in multibillion infrastructure projects in Central Asia. China like other major powers in the world, has been trying its best to keep Central Asia in its sphere of influence. For this they have huge investments especially in the energy sector with many oil and gas fields dominated by Chinese shares. After the Belt and Road Initiative, China has restructured its aid and investment to Central Asia bringing it all under the umbrella of BRI now.

However, utilizing Central Asian routes and resources is not an easy game. The biggest challenge in infrastructural development in Central Asia is its rugged terrain which hinders the development of many construction projects. Maneuvering through the mountains and using blasting techniques significantly increases the cost of these projects (Lamberte, 2006).Furthermore, the region has the presence of multiple actors especially USA and Russia who have their shares in the energy sector. That means that China cannot enjoy a monopoly over central Asian resources. 
Nevertheless, China has grand plans for Central Asia and is pouring in huge investments in the regions. In return, China has some expectations from Central Asia too. The Chinese aid and investment in Central Asia is comparatively with little strings attached (be it political or economic). Thus, by projecting the image of a benevolent lender, China asks for loyalty these critically important countries on the following issues:

- Containment of the Uighur uprising and taking steps to banish support for the separatist movement from within Central Asia.

- Help for locating dissonant under RATS (the Regional Anti-Terrorist Structure of the Shanghai Cooperation Organization). This is important as many terrorist enjoy cross border movements across Central Asia and it spills over to nearby Chinese provinces creating a security threat to these regions.

- Limited relations with Taiwan and diplomatic support of Chinese stance under the 'One China' principle.

- Silence on the Tibetan Issue

- Alignment and support of China in the UN Security Council (Yu, 2017; Beeson, 2018)

This benevolent aid also creates two significant problems for the Central Asian states. First is the lack of investment in soft infrastructure. Even though the development of hard infrastructure by China should eventually lead to better working environments, better professional ethics, political sustainability and human resources growth but unlike the expectations Central Asian countries are struggling to develop their human capital. The business environment lacks professionalism, brain drain leads to unutilized human capital and political and social fabric of these countries continues to suffer from corruption, poverty and lack of educational and professional development. This poses a significant threat to BRI's success as most of the hard investments can only be utilized if human capital is present to handle the influx of trade (Beeson, 2018).

Secondly, the huge amount of these loans make these countries fall under a vicious circle of Chinese debt where the economic systems of these countries are becoming increasingly debt- dependent. According to Laruelle, about 40 percent (or US\$1.5 billion) of Kyrgyzstan's public debt, and 50 percent (or US\$1.1 billion) of Tajikistan's, is owed to Chinese institutions (mainly, China Export-Import Bank, or Exim Bank). This potential loss of autonomy is a major fear shared by many participant countries of BRI.

\section{An Analysis:}

It is almost impossible to comprehend present world without economy. After disintegration of USSR a new race for the attainment of power and influence has initiated. Although USA has attained the status of superpower but its position has never been unchallenged. Steadily and gradually, Chinese economy has treading upon the track of development and success. Announcement of BRI has actually brought the notion of Chinese economic supremacy to a verge of unfolding reality. A mega economic plan to bring more than half of a world under a shared economy, where nations would sink and swim with China, has now become a reality which is about to be operated in near future. It is a plan of constructive economic hegemony with an aspiration of reaching to the culmination of glory. On the other hand, BRI is being taken as challenge especially by USA.

BRI is a manifestation of Chinese plans to take over global economy by strong. Some experts call it an imperial rendezvous to expand its economic and global influence. In fact, BRI is going to be a very lucrative plan for China, its economy and its global position. But there might be some global and regional challenges which can impede and threaten the workings of this initiative. On the global level, America is taking this initiative as a direct challenge to its hegemonic global economic position. On the regional level, India is insecure about its strong position in the South Asian region because India and China have never been on very good terms. Additionally, internal security situation of Pakistan and political instability in Afghanistan pose further threats to BRI. This plan can actually initiate some serious regional conflicts if all regional parties are not taken under confidence. In short, BRI is a huge project which would enhance China's global image, strengthen its economy, increase Chinese influence on regional and global politics but this plan can face a few global and regional challenges as well. Therefore, China has to find a strategy to play safe and come up with tenable solutions to forfeit global and regional insecurities related to this program.

\section{References}

[1] Ahmed, A., Arshad,M. A., Mahmood, A., \& Akhtar, S. (2017). Neglecting human resource development in OBOR, a case of the China-Pakistan economic corridor (CPEC). Journal of Chinese Economic and Foreign Trade Studies, 10(2), 130-142.

[2] Baltensperger, M. and DadushU.(2019). The Belt and Road turns five. Policy Contribution, Vol. 1, pp. 1-18. http://bruegel.org/wp-content/uploads/2019/01/PC01_2019_.pdf

[3] Baruah, D. M. (2018). "India's Answer to the Belt and Road: A Road Map for South Asia".CARNEGIE ENDOWMENT FOR INTERNATIONAL PEACE, https://carnegieendowment.org/files/WP_Darshana_Ba ruah_Belt_Road_FINAL.pdf

[4] Basit, S., Torjesen, S., \& Macfarlane, S. N. (2019). China in Pakistan and the wider region: A cautious but effective leader?. Contemporary South Asia, 27(1), 1526. 
[5] Beeson, M. (2018). Geoeconomics with Chinese characteristics:the BRI and China's evolving grand strategy. Economic and Political Studies, 6(3), 240256.

[6] Blanchard, J. M. F. (2018). China's twenty-first century Maritime Silk Road Initiative and South Asia: political and economic contours, challenges, and conundrums. In China's Maritime Silk Road Initiative and South Asia (pp. 1-31). Palgrave, Singapore.

[7] Cai, P. (2017). “Understanding China's Belt and Road Initiative". Lowy Institute, https://www.lowyinstitute.org/sites/default/files/docum ents/Understanding\%20China\%E2\%80\%99s\%20Belt $\% 20$ and\%20Road\%20Initiative_WEB_1.pdf

[8] China's Belt and Road Initiative (BRI) and Southeast Asia. (2018). ASEAN Research Institute, http://www.lse.ac.uk/ideas/Assets/Documents/reports/ LSE-IDEAS-China-SEA-BRI.pdf

[9] Chohan, U. W. (2018). What is one belt one road? A surplus recycling mechanism approach. In The Belt and Road Initiative (pp. 205-219). Brill Nijhoff.

[10] Haider K. and I. Dilawar. (October 26, 2016). "Militants Strike Pakistan, Hitting China's Economic Corridor". Bloomberg, https://www.bloomberg.com/news/articles/2016-1025/militants-return-topakistan-hitting-china-seconomic-corridor.

[11] Huang, Y. (2016). Understanding China's Belt \& Road initiative: motivation, framework and assessment. China Economic Review, 40, 314-321.

[12] Javaid, U. (2016).Assessing CPEC: Potential threats and prospects. Journal of the Research Society of Pakistan, 53(2).

[13] Lamberte, M. B. (Ed.). (2006). Beyond Microfinance: Building inclusive rural financial markets in Central Asia. Asian Development Bank.

[14] Laruelle, M. (Ed.). (2018). CHINA'S BELT AND ROAD INITIATIVE AND ITS IMPACT IN CENTRAL ASIA. The George Washington University, Central Asia Program, https://centralasiaprogram.org/wpcontent/uploads/2017/12/OBOR_Book_.pdf

[15] Ling, L. H. M., \&Perrigoue, A. C. (2018). OBOR and the Silk Road Ethos: An ancient template for contemporary world politics. Asian Journal of Comparative Politics, 3(3), 207-218.
[16] Lu, H. Rohr, C. Hafner, M. \& Knack. A. (2018). "China Belt and Road Initiative-Measuring the impact of improving transportation connectivity on trade in the region." RAND, https://www.rand.org/content/dam/rand/pubs/research_ reports/RR2600/RR2625/RAND_RR2625.pdf

[17] Madan, T. (2016). "What India Thinks about China's One Belt, One Road Initiative (But Does Not Explicitly Say)", Brookings Institution, https://www.brookings.edu/blog/order-fromchaos/2016/03/14/whatindia-thinks-about-chinas-onebelt-one-road-initiative-but-doesnt-explicitly-say/.

[18] McKenzie, B. (2017). Belt \& Road: Opportunity \& Risk The prospects and perils of building China's New Silk Road. https://www.bakermckenzie.com//media/files/insight/publications/2017/10/beltroad/baker_mckenzie_belt_road_report_2017.pdf

[19] Mitrovic, D. (2018). China's Belt and Road Initiative: Connecting and transforming initiative. In The Belt \& Road Initiative in the Global Arena (pp. 17-34). Palgrave Macmillan, Singapore.

[20] Singh, A. G. (March 02, 2019). China's Vision for the Belt and Road in South Asia- What progress has the BRI made in South Asia thus far? The Diplomat, https://thediplomat.com/2019/03/chinas-vision-for-thebelt-and-road-in-south-asia/

[21] Singh, A.G. (March 15, 2019). "China's "South Asia challenge" for the Belt and Road Initiative." Lowy Institute, https://www.lowyinstitute.org/theinterpreter/china-south-asia-challenge-belt-and-roadinitiative

[22] Small, A. (2017). First movement: pakistan and the belt and road initiative. Asia Policy, 24(1), 80-87. (Small,2017)

[23] UNDP. (2017). The Belt and Road Initiative- A new means to transformative global governance towards sustainable development. United Nations Development Programme China Center for International Economic Exchanges, https://www.undp.org/content/dam/china/docs/Publicat ions/UNDP-CH-GGR\%202017.pdf

[24] Wolf, S. O. (2016). China-Pakistan Economic Corridor (CPEC) and its impact on Gilgit-Baltistan. South Asia Democratic Forum (SADF).

[25] Yan, J. (2018). "The BRI in Southeast Asia." In China's Belt and Road Initiative (BRI) and Southeast Asia, Asean Research Institute, pp. 4-9. http://www.lse.ac.uk/ideas/Assets/Documents/reports/ LSE-IDEAS-China-SEA-BRI.pdf 
[26] Yang, Z. (2018). "Securing China's Belt and Road Initiative". United States Institute of Peace, https://www.usip.org/sites/default/files/2018-

11/sr_436_securing_chinas_belt_and_road_initiative_ web.pdf 